\title{
e-interview
}

\section{Mark Salter}

Mark Salter is a consultant in adult general psychiatry in London's East End. He trained at the London Hospital (now Royal London Hospital). His special interests include risk, untowardness and media portrayals of mental distress.

If you were not a psychiatrist, what would you do?

Anything else that obliges me to consider the chaotic splendour of human nature: film maker, writer, painter, journalist even.

What has been the greatest impact of your profession on you personally?

It has made me realise just how far we still have to go to before we can begin to use our knowledge of mental life to make the world a better place.

\section{Do you feel stigmatised by your profession?}

Less so as our profession is slowly recovering from the inferiority complex bestowed upon it by the pointless divide between mind and brain

What are your interests outside of work?

Writing, painting, film making, playing the piano and speaking French badly.

Who was your most influential trainer, and why?

Dr Ruth Seifert taught me that patience and humour are clinical skills and DrTrevorTurner taught me the art of creative doubt, but I owe just as much to the social workers Golda Behr, PercyAggett and Jimmy Glass, who taught me that if your principal intervention is based on drugs, you are wasting your time.

What job gave you the most useful training experience?

Senior house officer (SHO) in the psychiatric emergency clinic at Hackney Hospital. I clerked about four new patients five days a week for eight months. I reckon I must have seen the entire of ICD-9 (as it then was) over that time; the current fashion for closing these clinics is a form of insanity.

Which publication has influenced you most?

My new book, co-authored withTrevor Turner, entitled Outdoor Psychiatry. Otherwise, either The Brothers Karamazov by Dostoevsky, Candide by Voltaire or Catch-22 by Joseph Heller. Descarte's Error by Antonio Damasio is a non-fiction masterpiece.

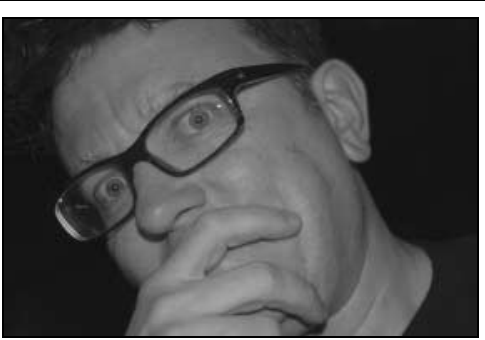

patient's own language of illness and recovery.

What is the most important advice you could offer to a new trainee? Go to the movies, read a lot and listen closely to people who seem able to use their skills to make a positive difference for their patients.

What are the main ethical problems that psychiatrists will face in the future?

How has the political environment influenced your work?

am fascinated by the observation that so much distress and suffering still provokes so much political indifference; I find politician's disinterest very interesting.

What part of your work gives you the most satisfaction?

Seeing someone get fully back into the swing of life after coming off of section three.

What do you least enjoy?

Meetings to decide whether or not to hold a meeting; our civilisation has got a serious problem distinguishing between form and content. People in power have a vested interest in blurring the difference between the two.

What is the most promising opportunity facing the profession? The growing realisation that a workable synthesis of biological, psychological and social knowledge is no longer clinically irrelevant.

\section{What is the greatest threat?}

Our growing obsession with risk. Risk is the new, politically acceptable name for stigma. The College needs to campaign for greater awareness of the gulf between risk management and risk elimination.

\section{What single change would} substantially improve quality of care? Aiming to provide every patient on our books with the resources and enthusiasm currently reserved largely for forensic, asser tive outreach and early intervention services.

\section{What conflict of interest do you} encounter most often?

The need to discharge people with psychosis from the wards back into psychotogenic, crack-infested hellholes while they are still displaying positive symptoms, in order to make way for the next lot.

What is the role of the psychiatrist in countries emerging from conflict? To find an unpatronising way of translating what psychiatry can offer into a practice that most closely resonates with the
Reconciling the tension between our roles as carers, as custodians and as educators.

Do you think psychiatry is brainless or mindless?

Neither. The question is based on a false and harmful premise that there is a reliable difference between the two.

What is the role of the psychiatrist in rebuilding healthcare systems? To exploit the discomfort that inevitably arises whenever people with cash and influence are obliged to confront the true horror of madness. People usually only think about improving mental health services when things go wrong. We therefore need to fail spectacularly from time to time in order to stop failing spectacularly.

What single change to mental health legislation would you like to see? The implementation of all the recommendations of the Richardson Report into the reform of the Mental Health Act.

What single area of psychiatric practice is most in need of development?

The creation of a new breed of community gist, part social worker and part cognitivebehavioural therapy practitioner.

What single area of psychiatric research should be given priority? Efforts to take psychiatric diagnosis beyond mere description of syndromes and into a system usefully based on complex, scientific understanding.

\section{How would you like to be} remembered?

Difficult, as I haven't yet had a chance to do the things I would like to be remembered for, but I would be happy if I could go to my grave having made more people comfortable with the idea of being uncomfortable.

Dominic Fannon

doi: 10.1192/pb.bp.108.020271 psychiatric care worker; part pharmacolo- 